\title{
Universal Electronic Student Course Registration Model (U-ESCRM)
}

\author{
Ejiofor C. I. , Okon, Emmanuel Uko \\ Department of Computer Science, University of Port-Harcourt, Nigeria
}

Copyright $\bigcirc 2018$ by authors, all rights reserved. Authors agree that this article remains permanently open access under the terms of the Creative Commons Attribution License 4.0 International License

\begin{abstract}
Student course registration is an integral facet of university registration processes, which holistically cater for organizational resources: manpower and material. Although several approaches have been proposed in addressing student registration, this research paper provide a comprehensive approach with the aim of addressing comprehensiveness in courses registration through the integration of departmental units within the university into a single architecture framework. This architecture has the propensity in supporting organizational procedures and processes while lessening overhead costs associated with process depletions.
\end{abstract}

Keywords Model, Registration, Student, Student-registration

\section{Research Permeable}

Student's course registration is the process of registering and accommodating each student based on a predefined number of courses accepted within the institution (university), with the courses registered by each student used as a clustering or registration models in identifying the area of specialization within the institution [9]. The student registration process enables student to acquire the necessary authorized credentials within the institution [7]. The registration processes also cater for student academic records, enabling institution to plan, manage, organize and coordinate processes in a manner that minimize the organization resource efficiently [5]. It also determines which students will partake in certain courses within the institution, and for the administration to keep its records up-to-date. These registration processes are handled simultaneously and the information collected is used by members of the teaching or management staff to construct educational procedures. Specifically management staff utilizes this information in handling daily planning and organization [10]. Prompt registration, perhaps, could enhance the ease of examining students, proper student result preparation and manage university resources. Some institutions usually stipulate a week within the school resumption, other two to three weeks, all in the aim of achieving prompt registration [6]. The significant of student registration to institution management cannot be overemphasized.

Most institution previously adopted manual base registration in ascertaining the number of available student and forecasting for institution essentials such as infrastructure and needed equipment [3].The manual registration involves each student responding to predefined biography and demography information provided by each departmental unit in cognizance to faculty based courses. Each student is required to sign with appropriate date on this form with one copy subsequently given to each student and appropriate copies kept with administration for record purposes [10].

Overtime due to paper bureaucracy, processing student record required much time which invariably lead to student delay in courses registration. Paper registration also hampered prompt dissension of relevant academic and managerial information. The cost of paper purchase has also added to the overhead costs within the organization [5]; [9]. The aforementioned issues have gradually affected and constrained the benefits associated with manual registration. The advent of electronic devices: computers and its associated peripherals have provided an avenue where student registrations can be handled electronically with the hope of considerably lessening delay in student registration processes which have been decentralized in most universities [4].

This research paper provides a Universal Electronic Student Course Registration Model (U-ESCRM). This model comprehensively addresses student registration using a single unified framework.

\section{Review of Student Registration}

Student registration processes have been addressed with some notable approaches with their associated strength and weakness. These weaknesses provide an avenue in implementing enhancement through novel approach. Tables 1 provide a brief review of related literature pertaining to student courses registration. 
Table 1. Review of Related Review

\begin{tabular}{|c|c|c|c|c|c|}
\hline SN & Author (Year)/Title & Goal/ & $\begin{array}{c}\text { Strength/ } \\
\text { Finding }\end{array}$ & $\begin{array}{c}\text { Limitation/ } \\
\text { Weakness }\end{array}$ & Further Research \\
\hline 1. & $\begin{array}{c}\text { The University Student Registration System: a Case } \\
\text { Study in Building a High-Availability Distributed } \\
\text { Application Using General Purpose Components }\end{array}$ & $\begin{array}{c}\text { Registration/ } \\
\text { Admission }\end{array}$ & $\begin{array}{c}\text { Distributed } \\
\text { system approach }\end{array}$ & $\begin{array}{c}\text { Difficulty in model } \\
\text { usage }\end{array}$ & $\begin{array}{c}\text { Centralized system } \\
\text { not presented }\end{array}$ \\
\hline 2. & $\begin{array}{c}\text { Shreedevi et al. (2015) } \\
\text { Development of Online Student Registration System }\end{array}$ & $\begin{array}{c}\text { Online Registration } \\
\text { System }\end{array}$ & $\begin{array}{c}\text { SMS/Email based } \\
\text { registration }\end{array}$ & $\begin{array}{c}\text { Lack of Centralized } \\
\text { System }\end{array}$ & $\begin{array}{c}\text { Centralized system } \\
\text { not presented }\end{array}$ \\
\hline 3. & Ala'a (2013) & $\begin{array}{c}\text { Online Registration } \\
\text { System }\end{array}$ & $\begin{array}{c}\text { Web tools was } \\
\text { developed }\end{array}$ & $\begin{array}{c}\text { Difficulty in } \\
\text { integrating Universal } \\
\text { system }\end{array}$ & $\begin{array}{c}\text { Centralized system } \\
\text { not presented }\end{array}$ \\
\hline
\end{tabular}

Table 1 provides a brief description of previous works on student course registration, which clearly exemplifies one fundamental issue; comprehensiveness of student registration processes in addressing varied students from different faculty within the university. The design model will successfully provide an avenue for uniformity in student records. This model will address unambiguity at the point of student registration, thus saving needed times, effort and resources.

\section{Universal Electronic Student Course Registration Model (U-ESCRM)}

The proposed model: Universal Electronic Student Course Registration Model (U-ESCRM) addresses the lingering issue of comprehensiveness in course registration, identified as a fundamental limitation of existing researches. This model also implements an electronic approach, eliminating subjective decision making in student registration. The model provides an objective approach; in addressing comprehensive course registration along faculty line which is a plus compared with previous models. This model was designed with the aim of achieving ease of use while heightening security through user authentication. Figure 1 provides a graphical representation depicting the Universal Electronic Student Course Registration Model (U-ESCRM).

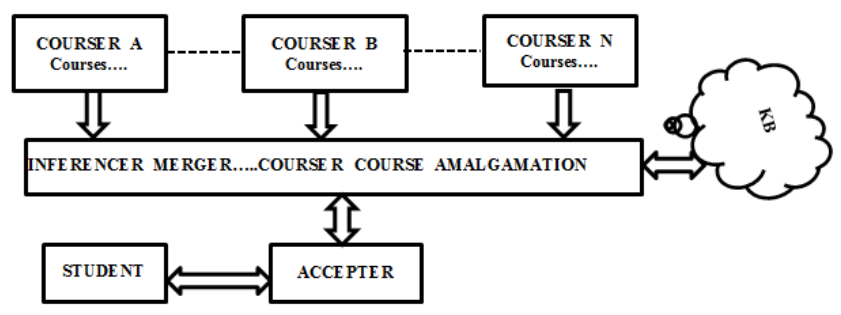

Figure 1. Universal Electronic Student Course Registration Model (U-ESCRM)

The presented model comprises of certain fundamental components which includes:

a Courser: The courser is the fundamental component of the U-ESCRM which provides the needed courses based on the course description, course content and institution curriculum. The course courser is department dependent and provides an avenue in collecting and collaborating content of each department covered within the Faculty

b Inferencer Merger: The inferencer Merger accepts and collates department courses into a universal framework catering for courses within the faculty. The inference merger also provides cumulatively the number of credits domiciled within the faculty. The information drawn by the inferencer meager is held within the knowledgebase, upon which the inferencer meager interacts. The inference merger also interacts with the Accepter getting relevant credential provided by the respective student users.

c KB: Knowledgebase: The knowledgebase serves as a central repository for model base information. These information are courses, course credits, student input information. The knowledgebase is the platform on which the courser merger runs on. The language of the knowledgebase is comprehended and understood by the courses merger, making it the sole repository and integrator for the courser information.

d Accepter: The accepter is the intermediary between the course merger and the student providing relevant input information. The accepter places the received information in the format understood precisely by the courser merger which is used in providing proper student registration.

e Student: The student is the main user of the model, providing the needed information upon which the model initiates, activate and transform student base information: student name, courses, course credit and even failed courses. The student input information must align with the department of interest and the faculty of resident, upon which a credentials is provided electronically for the student. These credentials are also saved for future purposes.

\section{Model Design}

The design of the Universal Electronic Student Course Registration Model (U-ESCRM) was handled using a 
standard Object Oriented design tool: Unified Modeling Language (UML). Unified modeling language (UML) is a standard modeling language used for modeling software models or systems. It provides a number of graphical tools that can be used to visualize a model from different viewpoints. The multiple views (user, structural, behavior, implementation and environment) of the system are represented by using various model diagrams [8]; [1]. This research paper focuses mainly on the user view. Figure 2 provide the user view depicting the facet of the Universal Electronic Student Course Registration Model (U-ESCRM).

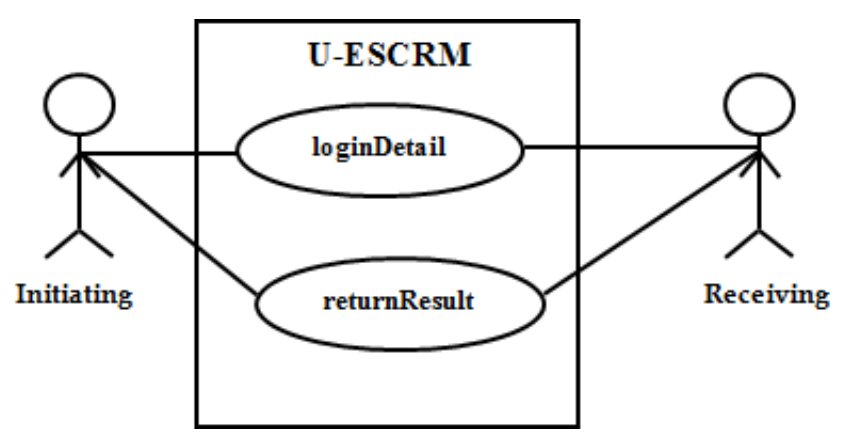

Figure 2. Use Case Diagram for U-ESCRM

\section{Discussion}

The Universal Electronic Student Course Registration Model (U-ESCRM) provides a universal, comprehensive and objective manner in addressing student course registration. The model on full implementation will provide significant benefits:

a Eliminate the slightest delay in course registration

b Efficient management departmental resources

c Promptly determines area of needs

d Forecasting efficiently with available resources

The aforementioned futuristic benefits indeed will indeed been the focus for implementing this model.

\section{Conclusions}

Student course registration indeed is an integral facet within the educational institution providing for adequate and efficient resource management aligned with available human resource. Although previous models have been designed to address automation and prompt registration the lingering issue of comprehensiveness in course registration has been addressed using: the Universal Electronic Student Course Registration Model (U-ESCRM).

\section{REFERENCES}

[1] Chris M. (2000), "Enterprise Modeling With UML: Designing Successful Software through Business Analyses, Addison Wesley. 7/4/2013

[2] Emma Boroson (2012), Course Registration, cs.brown.edu/courses/cs190/old.dhl2003/asgns/2-7/tmp/ebo roson_specs.pdf

[3] Johnson S (1999), Course Registration System Software Architecture Document Revision, retrieved online https://cs.uns.edu.ar/ mc/disenio/downloads/.../SAD-Cours eRegistration.pdf

[4] Little M. C., Wheater S. M., Ingham D. B., Snow C. R., Whitfield H. and. Shrivastava S. K (1994) retrieved online from

https://pdfs.semanticscholar.org/317f/75a7ac15f37a6d0535 01a1149238cef912d6.pdf

[5] Liu Y. (2012), Design and implementation of student registration system for Universities, retrieved online ieexplore.ieee.org/document/6202263/

[6] Naini V. R. (2008), A Web-Based Interactive Student Advising System Using Java retrieved escholarship.umassmed.edu/cgi/viewcontent.cgi?article=

[7] Norafizah A. R. (2011), A Prototype of Online Form One Student Registration System, retrieved online from etd.uum.edu.my/2745/2/1.Norafizah_Abdul_Razak.pdf

[8] Philippe K. (2000), "Rationale Unified Process: An Introduction: Second Edition, Addison Wesley

[9] Shreedevi B A, Ranjitha H. A, Priya S P., Swati D N., Prasanna k. M (2015) Development of Online Student Registration System, International Journal Of Innovative Research In Electrical, Electronics, Instrumentation And Control Engineering, Vol. 3, Issue 12, Pp. 22 - 24.

[10] Ting L. H. (2006), Online lab registration system - UNIMAS Institutional Repository, ir.unimas.my/.../ONLINE\%20LAB\%20REGISTRATION $\% 20$ SYSTEM $\% 2824 \% 20 \mathrm{pgs}$ 